\title{
KODEKS ETYCZNY JAKO INSTRUMENT SPOŁECZNEJ ODPOWIEDZIALNOŚCI BIZNESU
}

\author{
Wojciech Leoński \\ Uniwersytet Szczeciński \\ Wydział Nauk Ekonomicznych i Zarządzania
}

\begin{abstract}
Streszczenie: Koncepcja społecznej odpowiedzialności biznesu (CSR - Corporate Social Responsibility) staje się coraz bardziej popularna wśród polskich przedsiębiorstw. CSR dotyczy wielu obszarów działalności przedsiębiorstwa, wśród których znajdują się np. kwestie pracownicze. Osiągnięcie przez dany podmiot gospodarczy sukcesu na współczesnym rynku w dużej mierze uzależnione jest od kompetencji i umiejętności pracowników. Niewątpliwie stosowanie programów etycznych w firmie, w tym kodeksów etycznych, wpływa pozytywnie na pracowników, a także na wizerunek firmy w otoczeniu. Artykuł ma na celu dokonanie analizy kodeksu etycznego, jako istotnego narzędzia CSR. Podjęty temat badawczy został zrealizowany za pomocą metody krytycznej oceny, w tym: analizy literatury, raportów i opracowań wraz z wnioskowaniem.
\end{abstract}

Słowa kluczowe: kodeks etyczny, społeczna odpowiedzialność biznesu (CSR), strategia

DOI: $10.17512 /$ znpcz.2016.2.22

\section{Wprowadzenie}

Koncepcja społecznej odpowiedzialności może być ukierunkowana na otoczenie zewnętrzne i wewnętrzne przedsiębiorstwa. Otoczenie wewnętrzne to między innymi pracownicy, od których w dużym stopniu zależy sukces przedsiębiorstwa. Instrumentem CSR w obszarze pracowniczym są między innymi programy etyczne, które stają się coraz bardziej popularne w podmiotach odpowiedzialnych społecznie. Programy etyczne to działania podejmowane przez przedsiębiorstwa, mające na celu zbliżenie standardów firm i pracowników. Najbardziej rozpowszechnionym programem etycznym w przedsiębiorstwach jest kodeks etyczny. Jednym z kluczowych zadań programów etycznych jest instytucjonalizacja norm etycznych, gdyż zdecydowanie łatwiej jest przestrzegać pracownikom norm spisanych (Bem 2008, s. 171). Programy etyczne są zazwyczaj stosowane w przedsiębiorstwach dużych i średnich, które zatrudniają znacznie więcej pracowników niż podmioty mikro. Głównym celem artykułu jest dokonanie analizy kodeksu etycznego jako narzędzia CSR przynoszącego wymierne korzyści przedsiębiorstwom.

\section{CSR - identyfikacja pojęcia}

Jednoznaczne zdefiniowanie CSR jest rzeczą trudną, z uwagi na fakt istnienia wielu definicji poruszających aspekty ekonomiczne, społeczne, ekologiczne, etyczne itp. Dlatego też w artykule przytoczono kilka wybranych definicji celem zro- 
zumienia istoty koncepcji. CSR jest praktyką działania i coraz częściej wykorzystywanym narzędziem rozwiązywania problemów, minimalizowania ryzyka i poprawy reputacji organizacji. CSR postrzegane w kontekście zarządczym jest filozofią działania opartą na zasadzie poszanowania interesów wszystkich podmiotów funkcjonujących w otoczeniu organizacji (Rudnicka 2012, s. 16).

CSR to długofalowe podejście do prowadzenia działalności gospodarczej, polegające na: dobrowolnym przestrzeganiu przez przedsiębiorstwa zasad etyki, eliminowania negatywnego oddziaływania na społeczeństwo i środowisko naturalne, przy jednoczesnym maksymalizowaniu pozytywnego wpływu na otoczenie oraz uwzględnieniu, już na etapie budowy strategii, oczekiwań interesariuszy wewnętrznych i zewnętrznych, dialogu i współpracy (Szumniak--Smolej 2012, s. 55-77). Kwestie związane z CSR dotyczą działań biznesowych, które są nastawione na wspieranie szeroko rozumianego społeczeństwa i warunków, w których przebiega jego rozwój i życie, z równoczesnym maksymalizowaniem zysków materialnych (Stawicka 2015, s. 147-157). Przedsiębiorstwo CSR jest świadome konieczności przestrzegania zasad moralnych, a także obowiązku rozliczenia się z prowadzenia działalności gospodarczej przed społeczeństwem. Społeczna odpowiedzialność biznesu to nie tylko przestrzeganie prawa, ale też aktywność wykraczająca poza wymagania prawne dotyczące sprawozdawczości nałożone na przedsiębiorstwa, a mające na celu rozwój pracowników, dbałość o środowisko i dobre relacje z interesariuszami (Kryk 2011, s. 235).

Społeczna odpowiedzialność biznesu stanowi kompleksowy zestaw działań przedsiębiorstwa ukierunkowanych na ochronę środowiska naturalnego, pozytywne oddziaływanie na społeczność lokalną i globalną, a także pracowników. CSR to postępowanie firmy zgodne ze standardami etycznymi. Podmioty CSR są wrażliwe społecznie i ekologicznie, mają świadomość odpowiedzialności za przyszłe pokolenia. Nie należy zapominać, że podstawowym celem przedsiębiorstwa jest maksymalizacja zysków. Jednakże w przypadku CSR przedsiębiorstwo staje się odpowiedzialne za swoją działalność i oddziaływanie na otoczenie. Firmy CSR oprócz maksymalizacji efektów ekonomicznych starają się maksymalizować efekty prospołeczne i proekologiczne. Wdrożenie CSR może przynieść firmie szereg korzyści, takich jak poprawa wizerunku w oczach interesariuszy, pozytywny wpływ na pracowników, zwiększenie konkurencyjności. Dowodem na skuteczność CSR jest choćby stale rosnąca liczba podmiotów stosujących omawianą koncepcję. Przedsiębiorstwa odpowiedzialne społecznie działają w różnych obszarach. Ich dobór w dużej mierze zależy od kadry zarządzającej, warunków otoczenia czy też potencjału finansowego i zasobowego firmy. Najczęściej wybierane obszary w polityce CSR polskich przedsiębiorstw zostały przedstawione na Rysunku 1 .

Dokonując analizy danych zawartych na Rysunku 1, można zauważyć, że najbardziej popularnym obszarem CSR wśród polskich średnich i dużych przedsiębiorstw są społeczności lokalne (89\%). Do obszarów, w ramach których wprowadza się programy etyczne, można zaliczyć praktyki z zakresu pracy, które stosuje $59 \%$ przedsiębiorstw. Należy zauważyć, że programy etyczne są także powiązane z obszarem „prawa człowieka”, funkcjonującym w 43\% firm odpowiedzialnych społecznie. 


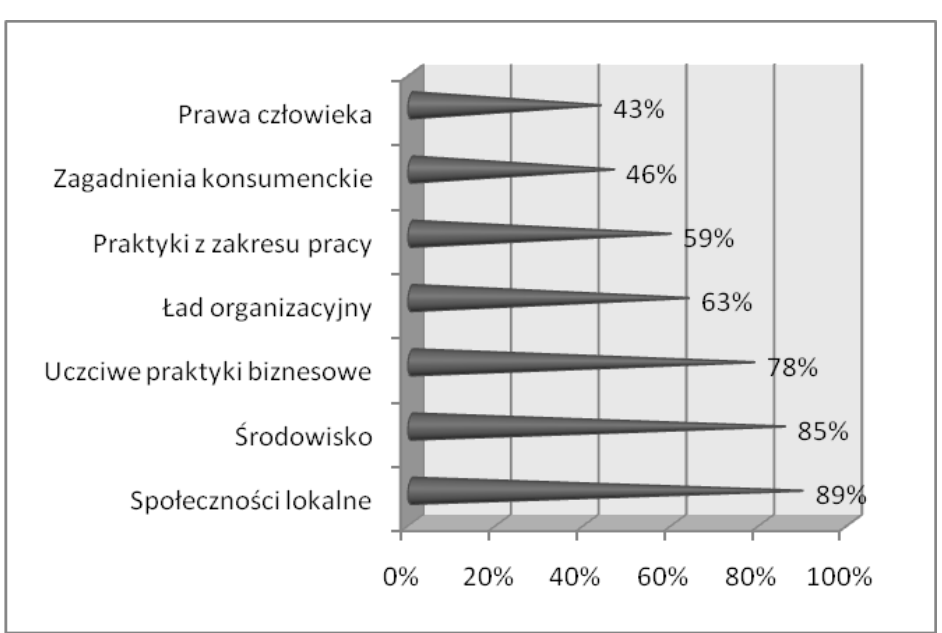

Rysunek 1. Obszary aktywności CSR średnich i dużych przedsiębiorstw w Polsce

Źródło: (KPMG w Polsce 2014, s. 27)

\section{Kodeks etyczny w polskich przedsiębiorstwach}

W celu poprawnej identyfikacji pojęcia „kodeks etyczny” należy zwrócić uwagę na dwa człony, tj. „kodeks” i „etyczny”. Słowo „kodeks” pochodzi z łaciny i oznacza księgę, spis. Zatem można stwierdzić, że jest to swoisty zbiór przepisów dotyczących danego zagadnienia. Natomiast „etyczny” to zgodny z zasadami etyki. Etykę można rozumieć jako ogół zasad i norm postępowania przyjętych w danej epoce i środowisku (http://sjp.pwn.pl/szukaj/etyka). Normy i zasady moralne pokazują, jak człowiek powinien postępować w danej sytuacji, przedstawiają mu, jakie działanie jest pozytywne, a jakie naganne. Opierając się na interpretacji powyższych pojęć, można zdefiniować kodeks etyczny w przedsiębiorstwie jako pisemne, formalne zestawienie zasad i norm postępowania wobec interesariuszy skierowane do osób zatrudnionych w danym podmiocie gospodarczym. Oczywiście istnieje możliwość funkcjonowania kodeksu etycznego w postaci przekazywanej ustnie, aczkolwiek taka forma posiada szereg wad, np. brak dostępu pracownika w dowolnej chwili do regulaminu. Kodeks etyczny jest regulaminem, w którym pracownik może znaleźć wzorce zachowań etycznych, może on zawierać praktyczne przykłady postępowania w różnych sytuacjach. Pisemny zbiór zasad etycznych powinien być dostępny dla każdego pracownika. Ponadto pracownicy powinni być $\mathrm{z}$ nim zaznajomieni, tylko wtedy może on pełnić swoje funkcje $\mathrm{w}$ przedsiębiorstwie. Dlatego też w firmach często organizuje się szkolenia związane z kodeksem etycznym, na których pracownicy są informowani o zachowaniach zgodnych i niezgodnych z kodeksem. Szkolenie takie często kończy się podpisaniem przez pracownika oświadczenia o znajomości i obowiązku przestrzegania zasad zawartych $w$ regulaminie. A. Stanek zwraca uwagę na sposób przekazania informacji dotyczących kodeksu etycznego. Samo przekazanie kodeksu pracownikowi do 
przeczytania nie wystarcza, gdyż nie daje możliwości wyjaśnienia wątpliwych kwestii i stwierdzenia, czy pracownik prawidłowo rozumie i interpretuje zapisy kodeksu. Ponadto istotny jest sposób uchwalenia kodeksu uwzględniający partycypację pracowników w jego tworzeniu (Stanek 2010, s. 263).

Kodeks etyczny to nic innego jak zbiór zasad, reguł i procedur, jakim podlegać ma pracownik $\mathrm{w}$ kontaktach $\mathrm{z}$ innymi pracownikami, partnerami biznesowymi, a także korzystając z zasobów. Powinien obejmować możliwie pełny katalog zachowań uważanych za etyczne oraz nieetyczne, określonych w sposób oddający wartości firmy, a nie w postaci zamkniętego katalogu niedopuszczalnych działań (Forum Odpowiedzialnego Biznesu 2009, s. 29). Kodeks etyczny to narzędzie dyfuzji norm moralnych, które odgrywa rolę wytycznych dla proetycznej orientacji podmiotu gospodarczego. Kodeks nie powinien być źródłem kontroli pracowniczej, gdyż jego istotą jest podejście prewencyjne (Rudnicka 2012, s. 165-166).

A. Barcik wymienia 3 podstawowe grupy tematyczne kodeksów etycznych: zasady normujące stosunki między pracodawcą a pracownikami, wskazówki i zalecenia związane z prawami i obowiązkami pracowników, zasady etycznego postępowania decydentów ukierunkowane na grupy zewnętrzne (Barcik 2000, s. 2). Struktura większości kodeksów etycznych opiera się na elementach takich jak: wstęp, określenie zasad ogólnych, następnie sformułowanie zasad bardziej szczegółowych, opis sposobów rozstrzygania sytuacji konfliktowych oraz określenie (choć nie we wszystkich kodeksach) sankcji, którym będzie podlegać osoba lub grupa osób niestosujących się do zasad zawartych w kodeksie etycznym (Janowski 2013, s. 241).

$\mathrm{W}$ podmiotach gospodarczych często tworzone są samodzielne stanowiska, np. rzecznik ds. etyki, lub specjalne komórki ds. etyki, np. Zespół ds. Kodeksu Etycznego. Celem takich stanowisk i komórek są często szkolenia, edukowanie, przekazywanie informacji, promowanie zasad zawartych w kodeksach etycznych wśród pracowników, ale także interesariuszy zewnętrznych. Ich zadaniem jest także rozpatrywanie zgłaszanych naruszeń regulaminów etycznych czy też wątpliwości co do podejmowania odpowiednich zachowań. Osoby zatrudnione na stanowiskach ds. etycznych pomagają egzekwować pożądane zachowania w przedsiębiorstwie, zapobiegają negatywnym zjawiskom, takim jak np. dyskryminacja w miejscu pracy i mobbing, nieprzestrzeganie standardów pracy, korupcja.

Przykładem komórki organizacyjnej ds. etyki jest Komitet ds. Etyki firmy Skanska stanowiący organ opiniodawczo-doradczy w przedmiocie obszaru etycznego. Składa się on z 9 osób, które ustalają wytyczne dotyczące zapytań i wątpliwości zgłaszanych przez pracowników w związku z zapisami dokumentów składających się na Program Kodeksu Postępowania Skanska. Komitet posiada kanał informowania o naruszeniu procedur, a jego członkowie zajmują się badaniem zarzutów i skarg pracowników, którzy mogą wysłać e-maila. Przykładem samodzielnego stanowiska ds. etyki jest Rzecznik ds. Etyki w spółce Bogdanka, który czuwa na straży Kodeksu Etyki. Do rzecznika można zgłaszać się w różnej formie: osobiście, telefonicznie, mailowo, anonimowo przy pomocy specjalnych skrzynek. Rzecznik zamieszcza informacje o Kodeksie w miejscach łatwo dostępnych dla zatrudnionych osób oraz na stronie internetowej spółki (Forum Odpowiedzialnego Biznesu 2014, s. 23-24). 
Narzędzie CSR, którym jest kodeks etyczny, jest z powodzeniem stosowane w różnych grupach polskich przedsiębiorstw. Przeprowadzone przez PARP badania pokazują, że kodeks etyczny jest najbardziej rozpowszechniony wśród małych (80\%) i dużych przedsiębiorstw (79\%). Kodeks etyczny jest najmniej popularny wśród podmiotów mikro $(66 \%)$ oraz średnich $(73 \%)$. Należy zaznaczyć, że dane te pochodzą z firm, które wdrożyły koncepcję społecznej odpowiedzialności biznesu (MillwardBrown SMG/KRC i PwC dla PARP 2011, s. 82). W przedsiębiorstwach kodeks etyczny przybiera różne nazwy, np. kodeks postępowania, kodeks etyki biznesu, kodeks dobrych praktyk, kodeks ds. etyki, kodeks wartości, kodeks procedur postępowania, kodeks współpracy, kodeks norm, zasady etyki biznesu. Ponadto kodeksy etyczne mogą też dotyczyć tylko wybranych obszarów działalności przedsiębiorstwa, np. kodeks dobrych praktyk w rekrutacji czy też kodeks ds. kontaktów z dostawcami.

\section{Funkcje i korzyści zastosowania kodeksów etycznych w przedsiębiorstwach}

Kodeksy etyczne pełnią dwie fundamentalne funkcje: wewnętrzną i zewnętrzną. Funkcja wewnętrzna jest skierowana do pracowników i kierownictwa przedsiębiorstwa i polega głównie na uświadomieniu i wskazaniu etycznego wymiaru działalności podmiotu poprzez edukację (Łukasiewicz-Kamińska 2011, s. 26). W ramach funkcji wewnętrznej istotną rolę odgrywa edukacja i informacja. Edukacja ta może odbywać się przy pomocy organizowanych szkolen, warsztatów, konferencji, informacji zamieszczanych na stronie internetowej firmy czy też na tablicy informacyjnej, przesyłania na służbową pocztę e-maili. W przypadku edukacji ważne jest, aby nie dotyczyła ona tylko kwestii teoretycznych, ale pokazywała np. praktyczne wzorce zachowania w różnych sytuacjach i warunkach. Sposób przekazania tej wiedzy powinien być przejrzysty i łatwo przyswajalny dla pracowników. Kodeks etyczny powinien przyczyniać się do wyszukiwania, analizowania i korygowania niepożądanych, nieetycznych zachowań $\mathrm{w}$ przedsiębiorstwie oraz $\mathrm{w}$ kontaktach $\mathrm{z}$ interesariuszami zewnętrznymi. Powinien udzielać rad i wskazówek pracownikom.

Funkcja zewnętrzna kodeksu etycznego jest związana z kształtowaniem wizerunku firmy. Niewątpliwie budowa pozytywnego wizerunku firmy i uzyskanie pożądanej reputacji nie są elementami możliwymi do osiągnięcia w krótkim okresie. Wizerunek i reputacja mogą być kluczowym źródłem uzyskania przewagi konkurencyjnej. Pozytywny wizerunek daje przedsiębiorstwu stabilność funkcjonowania i zmniejsza ryzyko. W trakcie spowolnienia gospodarczego podmioty CSR nie są tak bardzo narażone na spadek popytu, gdyż ich klienci są bardziej przywiązani do marki. Firmy te często mogą liczyć na większą przychylność inwestorów. Odpowiedni wizerunek może przełożyć się na obniżenie kosztów. Część inwestorów wiąże wiarygodność finansową przedsiębiorstwa $\mathrm{z}$ wiarygodnością społeczną. Zdarza się, że kontrahenci obniżają swoje ceny dla firm społecznie odpowiedzialnych, gdyż współpraca $\mathrm{z}$ takimi przedsiębiorstwami może zapewnić im stałą sprzedaż i poprawę własnego wizerunku. Niższe koszty firm CSR mogą wynikać także z lepszej wydajności pracowników utożsamiających się z działalnością firmy, a także z oszczędności surowców (Leoński 2015, s. 92-102). 
Do najczęściej wymienianych w literaturze zalet stosowania kodeksów etycznych zalicza się między innymi (Gasparski, Jabłońska-Bonca 2008, s. 223):

- oddziaływanie na prestiż organizacji,

- wpływ na rozwiązywanie konfliktów interpersonalnych,

- przyspieszenie procesu podejmowania decyzji,

- określenie i uzasadnienie granic odstępstw od norm prawnych,

- wpływ na rozwój społeczności lokalnych oraz środowisko naturalne,

- wpływ na współpracę z kontrahentami,

- uzupełnianie kontroli wewnętrznej i zewnętrznej pracowników.

Wymienione w artykule zalety wskazują, że kodeks etyczny w przedsiębiorstwie może stanowić ważny instrument zarządzania relacjami z pracownikami, który ogranicza niepożądane i nieetyczne zachowania oraz wpływa na kształtowanie kultury organizacyjnej. Odpowiedni klimat w firmie umożliwia między innymi lepszą integrację pracowników, sprzyja poczuciu przynależności do firmy, eliminuje konflikty i negatywne emocje, zwiększa motywację i efektywność pracowników. Właściwa kultura organizacyjna może być także instrumentem, który przyciąga potencjalnych pracowników do firmy. Warto zaznaczyć, że część osób, poszukując pracy, kieruje się nie tylko względami ekonomicznymi, np. pensją, ale także kwestiami związanymi z panującą w danej firmie kulturą organizacyjną. Szeroki wachlarz korzyści wywiera pozytywny wpływ na gospodarowanie, co może przyczynić się do odniesienia sukcesu na rynku.

\section{Podsumowanie}

Prawidłowo sformułowany kodeks powinien łączyć, a nie dzielić. Kodeks etyczny nie jest narzędziem, które ma zastąpić obowiązujące przepisy prawa i normy. Pełni on rolę edukacyjną i pomocniczą, wyznaczając właściwe wzorce zachowań w przedsiębiorstwie. Kodeks pomaga pracownikom dokonać wyboru, jak zachować się określonej sytuacji. Pracownicy przestrzegający zasad określonych w dokumencie obowiązani są do działania zgodnego z prawem, do przestrzegania zasad współżycia społecznego i dobrych obyczajów, bezstronności, przejrzystości, odpowiedzialności itp. Dla pracownika respektującego kodeks etyczny przedsiębiorstwo jest dobrem wspólnym, o które powinien dbać i czuć się za nie odpowiedzialny. Zbudowanie właściwych relacji z pracownikami oraz wizerunku firmy w otoczeniu to dwa główne elementy, które przemawiają za przydatnością kodeksów w przedsiębiorstwie. Dlatego też firmy odpowiedzialnie społecznie z powodzeniem stosują ten instrument, gdyż są świadome korzyści, jakie niesie.

\section{Literatura}

1. Barcik A. (2000), Etyka biznesu w zarządzaniu przedsiębiorstwem w polskiej gospodarce rynkowej, Agencja Wydawnicza Trio, Katowice.

2. Bem K. (2008), Programy społecznej odpowiedzialności biznesu jako element strategii przedsiębiorstwa, „Annales. Etyka w Życiu Gospodarczym”, vol. 11, nr 1, Archidiecezjalne Wydawnictwo Łódzkie, Łódź.

3. Forum Odpowiedzialnego Biznesu (2009), Firma = Etyka. Pracownicy. Dostawcy. Społeczeństwo, z. 1, Forum Odpowiedzialnego Biznesu, Warszawa. 
4. Forum Odpowiedzialnego Biznesu (2014), Odpowiedzialny biznes w Polsce 2014. Dobre praktyki, Forum Odpowiedzialnego Biznesu, Warszawa 2014.

5. Gasparski W., Jabłońska-Bonca J. (red.) (2009), Biznes, prawo, etyka, Wydawnictwo Akademickie i Profesjonalne, Warszawa.

6. http://sjp.pwn.pl/szukaj/etyka (dostęp: 01.01.2016).

7. Janowski M. (2013), Znaczenie kodeksów etycznych w procesie gospodarowania, [w:] Zagóra-Jonszta U., Nagel K. (red.) Współczesne problemy ekonomiczne. Wybrane zagadnienia teoretyczne a praktyka gospodarcza, Studia Ekonomiczne nr 129, Uniwersytet Ekonomiczny w Katowicach, Katowice.

8. KPMG w Polsce (2014), Społeczna odpowiedzialność biznesu: fakty a opinie, KPMG i Forum Odpowiedzialnego Biznesu, http://odpowiedzialnybiznes.pl/wp-content/uploads/2014/ 11/Raport-Spo\%C5\%82eczna-odpowiedzialno\%C5\%9B\%C4\%87-biznesu-fakty-a-opinieKPMG-FOB-20141.pdf (dostęp: 04.01.2016).

9. Kryk B. (2011), Raportowanie społecznej odpowiedzialności przedsiębiorstw za środowisko przyrodnicze, [w:] Kiziukiewicz T. (red.), „Zeszyty Naukowe Uniwersytetu Szczecińskiego” nr 625, Finanse, Rynki Finansowe, Ubezpieczenia nr 32, Wydawnictwo Naukowe Uniwersytetu Szczecińskiego, Szczecin.

10. Leoński W. (2015), Koncepcja CSR w polskim sektorze MSP, [w:] Rudny W. (red.), „Studia Ekonomiczne. Zeszyty Naukowe Uniwersytetu Ekonomicznego w Katowicach” nr 229, Wydawnictwo Uniwersytetu Ekonomicznego w Katowicach, Katowice.

11. Łukasiewicz-Kamińska A. (2011), Społeczna odpowiedzialność przedsiębiorstwa finansowego, Difin, Warszawa.

12. MillwardBrown SMG/KRC i PwC dla PARP (2011), Ocena stanu wdrażania standardów społecznej odpowiedzialności biznesu, PARP, Warszawa.

13. Rudnicka A. (2012), CSR - doskonalenie relacji społecznych w firmie, Wolters Kluwer, Warszawa.

14. Stanek A. (2010), Kodeks etyczny jako narzędzie zarządzania relacjami i pracownikami, Instytut Zarządzania PWSZZ w Oświęcimiu, Oświęcim.

15. Stawicka E. (2015), Korzyści ekonomiczne i społeczne wynikające z wdrażania zasad CSR na przykładzie polskich przedsiębiorstw, [w:] Boguszewicz-Kreft M. (red.), Przedsiębiorstwa i ich interesariusze - relacje marketingowe i CSR, Prace Naukowe WSB w Gdańsku, t. 42, CeDeWu, Gdańsk.

16. Szumniak-Smolej J. (2012), Druga generacja społecznej odpowiedzialności biznesu, [w: Płoszajski P. (red.), Społeczna odpowiedzialność biznesu w nowej gospodarce, OpenLinks, Warszawa.

\section{CODE OF ETHICS AS AN INSTRUMENT OF CORPORATE SOCIAL RESPONSIBILITY}

Abstract: The concept of corporate social responsibility is becoming more popular among Polish companies. CSR applies to many areas of the company, among which are eg. labor issues. The economic success of enterprises in today's market largely depends on the competence and skills of employees. Undoubtedly, the use of ethical programs in the company, including code of ethics has many positive effects on employees, as well as the company's image in the environment. The main goal of this article is the analysis of the code of ethics as an important tool of CSR.

Keywords: corporate social responsibility, code of ethics, strategy 